DOI

\title{
СТАН ВАЗОАКТИВНИХ ПЕПТИДІВ, ГОРМОНІВ І НЕЙРОМЕДІАТОРІВ У ХВОРИХ НА ХРОНІЧНЕ ОБСТРУКТИВНЕ ЗАХВОРЮВАННЯ ЛЕГЕНЬ У ПОЄДНАННІ 3 ГІПЕРТОНІЧНОЮ ХВОРОБОЮ
}

\author{
Харківський національний медичний університет
}

РЕЗЮМЕ. У роботі представлені дані дослідження рівня вазоактивних пептидів, гормонів та нейромедіаторів і динаміка їх змін у хворих на хронічне обструктивне захворювання легень (ХОЗЛ), поєднане з гіпертонічною хворобою (ГХ), на підставі яких можна обґрунтувати групи ризику у хворих на поєднану патологію. Отримані дані вказують на більш збалансовану кооперативну взаємодію гіпотензивних і пресорних механізмів у хворих при формуванні ХОЗЛ.

КЛЮчОВІ СЛОВА: хронічне обструктивне захворювання легень, гіпертонічна хвороба, вазоактивні речовини.

Вступ. На сьогодні серед пріоритетних проблем клінічної професійної патології хронічне обструктивне захворювання легень (ХОЗЛ) займає одне з провідних місць. Згідно з даними Всесвітньої організації охорони здоров'я, ХОЗЛ займає третє місце серед 10 провідних причин смерті на 2013 рік, що складає 3,1 млн чоловік [1]. Серед етіологічних факторів формування даної професійної патології важливе місце належить порушенням кооперативної взаємодії інтегративних систем контролю гомеостатичної функції організму (нервова, ендокринна, імунна), інфекційному фактору, шкідливим виробничим і несприятливим побутовим умовам. Аналіз наукових джерел свідчить, що за відсутності державних профілактичних заходів, загальна смертність від цієї патології в найближчі 10 років може зрости більш ніж на 30 \%. Необхідно зазначити, що прогноз тяжкості перебігу ХОЗЛ в значній мірі визначається супутніми змінами з боку серцевосудинної, нервової, імунної систем і поєднаних 3 ними порушень мікроциркуляції судинного русла, тканинного обміну і стану внутрішніх органів і тканин. Найчастіше в клінічній практиці у хворих на ХОЗЛ зустрічаєТься така поєднана патологія як гіпертонічна хвороба (ГХ). Дослідження багатьох авторів свідчать, що поєднання ГХ та ХОЗЛ становить в середньому 34,3\%. Спільними патогенетичними ланцюгами розвитку ХОЗЛ, а також ГХ $\epsilon$ формування ендотеліальної дисфункції у малому та великому колах кровообігу, підвищення активності симпатичної нервової системи, дисбаланс ерготропної і трофотропної функцій організму, порушення функції легень в метаболізмі вазоактивних речовин, розвиток оксидативного стресу, хронічного системного запалення, дисбалансу ренін-ангіотензин-альдостеронової системи [2]. Недостатньо вивченими залишаються і питання ролі ендотеліальної дисфункції у формуванні змін системного артеріального русла у хворих на ХОЗЛ із супутньою ГХ. Актуальним $\epsilon$ питання профілактики поєднаної патології та визначення груп ризику, а це диктує необхідність подальшого вивчення механізмів розвитку ускладнених форм ХОЗЛ.

Метою роботи $\epsilon$ вивчення вмісту в плазмі крові хворих на ХОЗЛ і у пацієнтів з поєднанням ХОЗЛ та ГХ вазоактивних пептидів, гормонів $\mathrm{i}$ нейромедіаторів, та обґрунтування групи ризику поєднаної патології.

Матеріал і методи дослідження. Відповідно до програми дослідження було обстежено 145 пацієнтів, які перебували на обстеженні та лікуванні в НДІ гігієни праці та професійних захворювань ХНМУ. Пацієнти були поділені на 3 групи:до основної групи були увійшли хворі, яким було встановлено діагноз ХОЗЛ з супутньою ГХ (55 осіб: 35 чоловіків і 20 жінок); до групи порівняння увійшли хворі на ізольоване ХОЗЛ (45 осіб: 34 чоловіки і 11 жінок); група контролю складалась 3 практично здорових осіб (45 осіб: 25 чоловіків і 20 жінок). Середній вік пацієнтів всіх трьох груп складав $(55,4 \pm 10,7)$ років і знаходився в інтервалі від 44,7 до 66,1 року. До завдання дослідження входило визначення в плазмі крові як хворих, так і умовно здорових пацієнтів вазоактивних пептидів, гормонів і нейромедіаторів. Із пептидів плазми крові досліджували карбоксикатепсин (пептидилдипептидаза або кіназа 2), карбоксипептидаза-N (кіназа 1), калікреїн і калікреїноген, ренін і вазоактивний кишковий пептид (VIP). До вазоактивних гормонів були залучені альдостерон і антидіуретичний гормон (АДГ) - вазопресин, а із нейромедіаторів - адреналін і норадреналін.

Пептидил-дипептидаза $\epsilon$ ангіотензинперетворювальним ферментом і каталізує перетворення ангіотензину I в ангіотензин II (вазоактивний судинозвужувальний пептид) та руйнує бра- 
Огляди літератури, оригінальні дослідження, погляд на проблему

дикінін (судинорозширювальний пептид). Його активність визначали спектрофлуориметричним методом [3-6]. Карбоксипептидаза-N (кіназа 1) фермент, який інактивує брадикінін шляхом відщеплення С-кінцевого аргініну. Визначали кіназу-1 спектрофлуориметричним методом за гідролізом ефірного зв'язку гіпурил-L-аргінінової кислоти (ГАК) $[3,6]$. Ренін, вазоактивний кишковий пептид і альдостерон досліджували в плазмі крові методом імуноферментного аналізу (ІФА) $[7,8]$. Антидіуретичний гормон (АДГ) - вазопресин визначали методом радіоімунного аналізу [9]. Калікреїн і калікреїноген - ферменти протеази, що беруть участь у розщепленні кініногенів у білковій фракції $\alpha_{2}$-глобулінів з утворенням брадикініну. Активність калікреїну визначали спектрофотометричним методом за швидкістю гідролізу N-бензол-L-аргінін етилового ефіру (BAEE) [3, 10-13]. Адреналін і норадреналін у плазмі крові визначали флуориметричним методом за утворенням адренолютину і норадренолютину [9]. Статистичне опрацювання отриманих результатів здійснювали з використанням критерію Стьюдента-Фішера.

Результати й обговорення. Результати дослідження вазоактивних субстратів у плазмі крові виявили у пацієнтів, які страждають на ХОЗЛ у поєднанні з ГХ, підвищення пептидил-дипептидази на 99,58\%, порівняно з групою контролю (табл. 1). Це дає можливість стверджувати, що даний фермент активує утворення пресорного пептиду ангіотензину II із ангіотензину І у цієї категорії паці$\epsilon$ єтів. Щодо групи хворих на ізольоване ХОЗЛ, то активність пептидил-дипептидази (кінази 2) у них вірогідно не змінювалась, порівняно з групою порівняння, хоча й мала тенденцію до підвищення $[3,4]$. Необхідно зазначити, що суттєве підвищення пептидил-дипептидази (АПФ) у основній групі пацієнтів може бути поєднано із активацією процесів судинорозширювального пептиду брадикініну. Визначення кінази-1 (карбоксипептидаза-N) у плазмі крові виявило підвищення ії рівня на $64,20 \%$ у хворих на ХОЗЛ з супутньою ГХ, що вказує на інактивацію в цій групі брадикініну, тоді як у групі порівняння активність карбоксипептидази-N була на рівні практично здорових пацієнтів і мала тенденцію до підвищення. Відомо, що пептид ренін бере участь у перетворенні ангіотензиногену в ангіотензинlill.Результатидослідженняпоказали, що активність цього пептиду при ХОЗЛ у поєднанні з ГХ зростає на 56,45 \%, тоді як у групі порівняння цей показник був близьким до значень групи контролю. Вазоактивний кишковий пептид (VIP), який має гіпотензивно-судинорозширювальний ефект, був знижений в основній групі пацієнтів на $49,99 \%$, тоді як у пацієнтів з ізольованим
ХОЗЛ цей показник практично не відрізнявся від рівня умовно здорових пацієнтів. На цьому фоні антидіуретичний гормон - вазопресин - у групі пацієнтів з поєднаною патологією підвищувався в плазмі крові на $44,56 \%$, а в групі порівняння на 19,85 \%, порівняно з групою контролю. Вміст у плазмі крові альдостерону при ХОЗЛ, поєднаному з ГХ, був підвищений на $116,27 \%$, тоді як у хворих на ХОЗЛ цей показник не змінювався, порівняно з групою контролю. Дослідження свідчили про підвищення біогенних моноамінів - катехоламінів - як в основній групі, так і в групі порівняння: адреналін зростав на $33,17 \%$ і $17,28 \%$, а норадреналін на 80,45 \% і 20,90 \% відповідно в першій і другій групах хворих, порівняно з групою контролю (табл. 1). У першій групі хворих значно підвищувався норадреналін, що вказує на можливість суттєвої індукції пресорного ефекту даного нейромедіатора. Активність калікреїну і калікреїногену була знижена як в основній групі, так і в групі порівняння. Ці протеїнази каталізують в організмі відщеплення нанопептиду брадикініну або його N-кінцевих гомологів від неактивного попередника глікопротеїнової природи-кініногену. Дана реакція лежить в основі утворення вільних кінінів у циркулюючій крові, перикапілярних просторах, секреторних залозах, нирках і деяких інших органах та визначає в організмі ряд важливих фізіологічних функцій: регуляція мікроциркуляції регіонального кровотоку, рівня кров'яного тиску тощо [3-5]. Дослідження показали, що у Хворих на ХОЗЛ у поєднанні з ГХ рівень калікреїну підвищувався на $127,90 \%$, а у хворих з ізольованим ХОЗЛ - на 44,18\%. Калікреїноген у першій групі підвищувався в плазмі крові на $85,62 \%$, а у другій групі хворих на 59,78 \%. Така динаміка калікреїну та калікреїногену може бути обумовлена захисно-пристосувальною реакцією до пресорної дії вазоактивних пептидів і нейромедіаторів, яка спрямована на покращення мікроциркуляторних умов судинного русла і при ХОЗЛ.

Результати дослідження свідчать, що ХОЗЛ у поєднанні з ГХ перебігають на фоні активації ренін-ангіотензин-альдостеронової кооперативної взаємодії, яка супроводжується пресорним ефектом і значним напруженням захисно-пристосувальних механізмів, до яких залучені нирки, печінка, легені та серцево-судинна система. При поєднаній патології найвищі рівні були властиві таким показникам як АПФ, альдостерон, норадреналін і калікреїн, що вказує на значну активацію нейроендокринної системи і ії провідну роль у формуванні поєднаної з ХОЗЛ гіпертонічної хвороби. Аналіз показників у хворих на ХОЗЛ виявив невірогідне підвищення в плазмі крові пептидилдепептидази, карбоксипептидази-N і реніну на 
Огляди літератури, оригінальні дослідження, погляд на проблему

Таблиця 1. Стан вазоактивних пептидів у плазмі крові хворих на ХОЗЛ з супутньою гіпертонічною хворобою, та 3 ізольованим ХОЗЛ

\begin{tabular}{|c|c|c|c|}
\hline \multirow[b]{2}{*}{ Показники } & \multicolumn{3}{|c|}{ 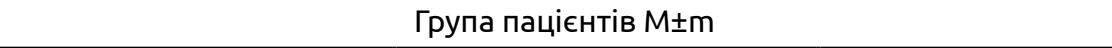 } \\
\hline & $\begin{array}{c}\text { основна група (ХОЗЛ+ГХ) } \\
\text { n=55 }\end{array}$ & $\begin{array}{c}\text { група порівняння (ХОЗЛ) } \\
\text { n=45 }\end{array}$ & $\begin{array}{c}\text { контрольна група } \\
\text { n=45 }\end{array}$ \\
\hline $\begin{array}{l}\text { Пептидил-дипептидаза-кіназа } 2 \\
\text { (АПФ), нмоль/мл•хв }\end{array}$ & $28,94 \pm 1,72$ * & $16,8 \pm 1,65$ & $14,5 \pm 1,36$ \\
\hline $\begin{array}{l}\text { Карбоксипептидаза-N (кіназа 1), } \\
\text { мкмоль ГАК/ мл•хв }\end{array}$ & $1,76 \pm 0,18$ * & $1,24 \pm 0,17$ & $1,13 \pm 0,15$ \\
\hline $\begin{array}{l}\text { Вазоактивний кишковий пептид, } \\
\text { нг/л }\end{array}$ & $13,2 \pm 1,14$ * & $25,47 \pm 1,96$ & $26,35 \pm 1,58$ \\
\hline $\begin{array}{l}\text { Антидіуретичний гормон (АДГ) - } \\
\text { вазопресин, пг/мл }\end{array}$ & $3,86 \pm 0,28$ * & $3,20 \pm 0,25$ * & $2,67 \pm 0,21$ \\
\hline Альдостерон, нМ/л & $0,93 \pm 0,07$ * & $0,48 \pm 0,06$ & $0,43 \pm 0,05$ \\
\hline Адреналін, нМ/л & $2,85 \pm 0,24$ * & $2,51 \pm 0,20$ * & $2,14 \pm 0,17$ \\
\hline Норадреналін, нм/л & $3,97 \pm 0,31$ * & $2,66 \pm 0,24$ * & $2,20 \pm 0,18$ \\
\hline Калікреїн, МО/мл & $9,8 \pm 0,65 *$ & $6,2 \pm 0,53 *$ & $4,3 \pm 0,36$ \\
\hline Калікреїноген, МО/мл & $388, \pm 31,2$ * & $334,6 \pm 22,4$ * & $209,4 \pm 17,8$ \\
\hline Ренін, нг/ мл • годину & $2,48 \pm 0,23$ * & $1,53 \pm 0,16$ & $1,40 \pm 0,12$ \\
\hline
\end{tabular}

Примітка. Різниця вірогідна $(p<0,05)$ з контролем.

фоні достовірного підвищення АДГ, адреналіну, норадреналїну, калікреїну та калікреїногену. Ці дані вказують на більш збалансовану кооперативну взаємодію гіпотензивних і пресорних механізмів у хворих при формуванні ХОЗЛ.

\section{ЛІТЕРАТУРА}

1. World health organization. The top 10 causes of death. Retrieved from http://www.who.int/mediacentre/ factsheets/fs355/en/.

2. Hunninghake D. Cardiovascular Disease in Chronic Obstructive Pulmonary Disease The Proceedings of the American Thoracic Society / Donald B. Hunninghake // ATSJournals. - 2005. - Vol. 2. - P. 44-49.

3. Орехович В. Н. Современные методы в биохимии / Василий Николаевич Орехович. - М. : Медицина, 1977. - 392 c.

4. Lee P. V. An improved colorimetric determination of amino acid with the use of ninhydrin / P. V. Lee, T. N. Takahashi // Analyt. Biochem. - 1966. - T. 14, № 1. - P. 71-77.

5. Kennedy A. R. Cancer Prevention by Protease Inhibitors / A. R. Kennedy // Prev Med. - 1993. - Vol. 22. C. $796-811$.

6. Соловьев В. Б. Активность пептидилдепиптедазы N в сыворотке крови пациентов с болезнью Альцгеймера / В. Б. Соловьев, М. Т. Генгин // Украинский биохимический журнал. - 2007. - № 6. - С. 103-105.

7. Direct renin assay and plasma renin activity assay compared / D. Hartman, G. A. Sagnella, C. A. Chesters, G. A. MacGregor // Clin. Chem. - 2004. - Vol. 50. P. 2159-2161.

8. Campbell D. J. Interpretation of plasma renin concentration in patients receiving aliskiren therapy /
Висновки. Інформативними показниками при діагностиці груп ризику ХОЗЛ з супутньою гіпертонічною хворобою можуть бути високі рівні АПФ, реніну, альдостерону і калікреїну.

D. J. Campbell // Hypertension. - 2008. - Vol. 51, № 1. P. 5-18.

9. Простые и макроциклические эфиры: научные основы охраны водных объектов / [В. И. Жуков, л. Д. Попова, О. В. Зайцева и др.]. - Харьков : Торнадо, 2000. -437 c.

10. Пасхина Т. С. Калликреин сыворотки крови человека. Активность фермента и хроматографический метод определения / Т. С. Пасхина, Г.А.Яровая // Биохимия. - 1970. - № 35 (5). - С. 1055-1058.

11. Пасхина Т. С. Калликреиноген сыворотки крови человека. Метод определения и некоторые свойства / Т. С. Пасхина, В. Л. Доценко, Е. И. Блинникова // Биохимия. -1973 . - № 38 (2). - С. 420-423.

12. Пасхина Т. С. Модифицированный хроматографический метод определения калликреина и прекалликреина в плазме (сыворотке) крови человека : методические рекомендации / Т. С. Пасхина, Р. И. Якубовская, Г. Е. Баженова. - М., 1984. - 7 с.

13. Пасхина Т. С. Упрощенный метод определения калликреиногена и калликреина в сыворотке (плазме) крови человека в норме и при некоторых патологических состояниях / Т. С. Пасхина, А. В. Кринская // Вопросы медицинской химии. - 1974. - № 20 (6). - C. 660-663. 
Огляди літератури, оригінальні дослідження, погляд на проблему

STATE OF VASOACTIVE PEPTIDES, HORMONES AND NEUROTRANSMITTERS IN PATIENTS WITH CHRONIC OBSTRUCTIVE PULMONARY DISEASE IN COMBINATION WITH HYPERTENSION

○V. A. Kapustnyk, O. V. Istomina

Kharkiv National Medical University

SUMMARY. The work presens the research of vasoactive peptides, hormones and neurotransmitters and their dynamic changes in patients with chronic obstructive pulmonary disease (COPD) in combination with hypertension on the basis of which grounds of risk for comorbidity. The data point to a more balanced and cooperative interactions of antihypertensive pressor mechanisms in patients with COPD formation.

KEY WORDS: chronic obstructive pulmonary disease, hypertension, vasoactive substances.

Отримано 4.04.2016 